Весна Половина*

\title{
СИНХРОНИЈСКА АНАЛИЗА УПОТРЕБЕ И ФУНКЦИЈА ПОСЛОВИЦА И ИЗРЕКА
}

Богата литература о пословицама и изрекама претежно се бавила анализом језика пословица, њиховим настанком, културолошким сличностима и разликама међу језицима, варијантама пословица у времену и простору, а тек у релативно новије време њиховом реалном употребом у одређеној језичкој заједници. Циљ нашег рада је да размотримо два могућа приступа изучавању савремене употребе и функција пословица: путем анкете и корпусне анализе. Одабравши један број пословица из Вуковог времена направљена је анкета чији је циљ био да се утврди разумевање значења изрека код данашњих одраслих младих говорника српског језика, увид у комуникативне ситуације у којима би се изреке могле употребити, и да ли постоје индикације о регионалним комуникативним моделима у њиховом разумевању и употреби. Потом је анализирано присуство тих пословица у доступним корпусима српског језика, како би се утврдило да ли се оне реално употребљавају и данас и какву им улогу дају говорници. Резултати показују да и данас постоји делимично разумевање изрека, али се углавном користе спорадично и примењују на савремене урбане ситуације и ситуације из личног искуства, тумаче данашњом лексиком, али и да постоје регионални комуникативни модели, као и да слика реалне употребе кроз анализу корпуса показује углавном сличне, али не и идентичне односе у погледу потпуног и делимичног разумевања и употребе истраживаних изрека. Наше истраживање показује не само предности и недостатке оваквих техника испитивања у осветљавању савремене употребе изрека и пословица већ указује на које начине могу допринети нашој спознаји о неким аспектима дијахронијског погледа на њихово преживљавање.

Кључне речи: пословица, корпус, анкета, српски језик

\footnotetext{
*_polovina.v@gmail.com;

**_zorkakasic@gmail.com
} 
Увод. Пословице као језички искази, кратке народне књижевне форме, 'микротекстови, биле су предметом истраживања већ стотинама година. Паремиологија и паремиографија су посебне дисциплине у оквиру савремене лингвистике, па и науке о књижевности и култури, чији су основни предмет истраживања управо пословице, али и њима сродне појаве, које се углавном могу сврстати у вишечлане лексичке изразе; то су идиоми (фраземи, фразеологизми), терминолошке синтагме, устаљени спојеви речи (колокације, везане групе речи), окамењени (фосилни) изрази, максиме, крилатице, наводи (цитати), слогани, итд. О интердисциплинарности која се подразумева у истраживањима оваквих и сличних појава говори и Рајна Драгићевић (Драгићевић, 2010), показујући, на случају вербалних асоцијација, важност лингвокултуролошког приступа лексици.

На ком ће се плану, синтагматском или парадигматском, терминолингвистичком, лексиколошком, паремиолошком, или текстуалном, пословице посматрати, зависи често од тога шта се истражује, од теоријског приступа, али и од филолошке традиције и сл. Тако ће се у паремиолошким збиркама често наћи примери који се могу приписати не само једном већ и неколиким типовима ових израза, што делом произлази из њихове природе, а делом и због недовољно прецизираних критерија којима су се руководили приређивачи и скупљачи. С обзиром да наше истраживање почива на одбиру од 16 пословица, чији статус није проблематичан у том смислу, ми се нећемо даље бавити овим недостатком стриктног разграничења између типова вишечланих израза, већ само истаћи оно што је теоријски битно за нашу тему.

Ипак, нека обележја пословица, која често истичу у литератури о пословицама, потребно је да наведемо у овом уводу.

С обзиром да је настанак и историјат пословица једна од веома заступљених тема паремиологије, данас је добро познато да су неке пословице настале још у античка времена или из религиозних светих списа: Јеgна ластиа не чини йролеће, Ко gруїоме јаму койа, сам ће у юу $\bar{u} а с \bar{u} u$, Пас који лаје не ујеgа и сл. Да ли због утицаја културе или религије, свеједно је, оне су посведочене у десетинама језика (Mieder, 2004, стр. 11), те су постале део народних традиција у многим културама. Наравно, говори се и о регионалним и националним варијацијама (Афричка пословица: Лав који риче не убија gивљач - A roaring lion kills по game - на енглеском, свакако је јасна варијација пословице „Пас који 
лаје не уједа“"). Штавише, за пословице се или каже да су изразито културно обележене или да су обележје народне културе, чиме се истиче њихова специфичност, или се истиче њихова универзалност. Овај други став налазимо рецимо код Чемпиона (Champion, 1966): "Proverbial wisdom is exactly the same all the world over, [...] Fundamentally, psychologically, they [men] are the same, oriental or accidental, pigmental or white; love, hunger, and fear are the basic factors that rule mankind, primitive or cultured; factors uninfluenced by environment or civilization. И заиста, тематски и садржински гледано, као историјске, временске, етничке, етичке, дијалошке, медицинске, и сл., све пословице се баве оним што је важно за човека, категоризују и вреднују појаве, па су и разлике више на нивоу реалија на које се ослањају него по општим судовима. Ово је свакако један од разлога што неке пословице које први пут чујемо тежимо да протумачимо, углавном, мада не увек, успешно. То ће показати и резултати нашег истраживања.

Другим речима, употреба и постојаност пословица, која, како сви признају, може да се мења током времена и то у зависности од промена у човековој средини, у друштву, технологији и сл. подразумева стална истраживања њихове реалне употребе у комуникацији, што није једноставан задатак. Зашто неке опстају и имају ширу употребу, док неке нестају полако? Неки разлози су очити.

Очите језичке разлоге налазимо рецимо, не нужно у данас непознатим „реалијама“, већ и у застарелој лексици. У својем значајном делу о пословицама у српском језику, Јовановић Симић наводи примере таквих пословица из Вукове збирке: Мјешина муста їлава йy-

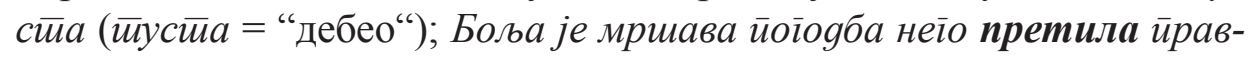
gа; Ко с вашкама сйава, найуни се буха (вашка - турцизам, у значењу "пас") Лажаи и скупац лако се йоі̄oge, (скуйац у значењу „шкрт“) (Јовановић, 2006, стр. 939).

Други разлог који бисмо могли навести је чињеница да пословице често обилују фигуративним значењима. Док се појединачне лексеме (за сродство, боје и сл.) прве почињу усвајати у матерњем и страном језику још од најранијих стадијума, фразеологизми, и још више пословице, не уче се нити усвајају од почетка, а један од разлога је управо њихова специфична форма и семантика - наиме, дете није у стању у првим годинама усвајања матерњег језика да разуме фигуративан, метафорички израз који је често врло јасно у основи 
фразеологизама и других вишечланих израза. С друге стране, управо поетизована форма пословица, не само због фигура значења, већ са стилским обележјима због којих се представљају и као кратке уметничке фолклорне форме, дакле - ритма, риме, алитерације и асонанције, синтаксичког паралелизма, парадокса, ироније, игре речи, и сл., основни је разлог што се пословицама приписује функција „оживљавања“ и „експресивности“ комуникације. Засхваљујући томе, оне су „упечатљивије“ и лакше се памте.

С обзиром да садржински пословице (као и неке друге фолклорне форме) уопштавају ситуације или сплетове стуација, битне за човека, а та уопштавања се сматрају (у народу) општеприхваћеним ставовима, истиче се често њихова дидактичка функција. Оне уздижу врлине, вредноћу, чистоту, исмевају лењост, снобизам, неморал, итд. Старија генерација подучава децу да не краду, не лажу, и сл. Због тога се често њима посвећује посебна пажња у настави матерњег језика. Поред ове функције, приписују им се, рецимо, и рефлективна. Психолошки се помоћу пословица рационализује нека проблематична ситуација, користи се аналогија као когнитивни процес и тако ублажавају социјални конфликти, незадовољство појединца, и сл. Својом поетском формом пословице дају боју, живост, али служе и као когнитивна и реторичка средства у “правном” језику, код доношења одлука, за истицање закључка, да би се извели неки говорни чинови попут упозорења, охрабривања и други.

Са аспекта превођења и учења страног језика, пословице представљају такође важан део кутуролошких и језичких питања, јер се и у преводима, па и у савладавњу вештина комуникације на страном језику, пословице могу јавити, често чак у скраћеном облику, припадају општем знању језика којим влада изворни говорник, док преводилац или ученик је не познају, те им то може бити проблем. Стога су многи сматрали да се одређеним минималним фондом пословица (наравно и других сличних израза) мора овладати како би се успешно преводило или досегао одређени степен знања страног језика.

С обзиром да се паремиолошки минимум или честа употребе једног броја пословица постављају као темељ оваквих методичких поступака у настави матерњег или страног језика, потребно их је што поузданије одредити. Два су основна приступа. За први, којим се на основу анкета и интервјуа утврђује које су пословице општепознате у једној језичкој заједници, најзаслужнији је, и незаобилазан, Л. Г. Пер- 
мјаков. Према Е.Е. Иванову, (2009) у оквиру структуралне паремиологије Л.Г. Пермјакова, утврђено је да минимални број општепознатих паремија износи 300, док максимални број често употребљених пословица не прелази бројку од 500. Пермјаков је то утврдио путем „експеримента“, који се спровео у две етапе. Најпре информантима понудио 1494 паремије са задатком да одговоре колико им је позната свака од њих, а потом је одабрано 538 исказа који су били непотпуни, те их је требало довршити. На пример, Сказано - ?... (Сказано - cgeлано); Тише еgешь - ?... (Тише еgешь - gальше будешь). (Иванов, 2009, 37). Испитаника је било око 250.

Међутим такав поступак, према Иванову (2009), има своје недостатке. Избор паремија је био субјективан, истраживачев списак, затим територијално ограничен на Москву и њену околину, а информанти пажљиво бирани. Последица тога је била да се неке познате пословице (Хороша Маша, gа не наша) нису нашле у списку општепознатих, а увршћене су неке (нпр. Ней розы без шийов) за које аутор није сигран да су општепознате код Руса. Осим тога, занемарена је дијахронијска димензија, јер је Пермјаков утврдио минимум за другу половину двадесетог века, што искључује екстралингвистичке факторе (културне приоритете одговарајуће епохе, утицај разних социјалних и демографских катаклизми, смене погледа на свет и сл.) (Иванов, 2009, 137-139). Међутим, и сам аутор овог приказа не пружа доказе о томе да су неке заиста општепознате, те се ова врста критике, о „субјективности“ одбира пословица може применити и на друге ауторе.

Други поступак одређивања општепознатости пословица базиpa се на истраживањима корпуса одређеног језика. Чермак (С̌ermak, 1998), жели да упореди резултате претходног испитивања на основу велике анкете Ф. Шиндлера (Schindler, 1993), утврдио „паремиолошки минимум“ за чешки језик (од 99 пословица), са „стварном употребом“ на корпусу чешког језика, који износи око 23 милиона речи-токена. Утврдио је да се јављају 284 пословица у том корпусу. Нека битна методолошка ограничења свог истраживања је назначио сам Чермак. Прво, да се ради о употреби више у смислу продукције језичке, а не рецепције, јер су корпуси типично, па и онај на који се он ослања, састављени од малог броја говорника/аутора, односно углавном новинара и књижевника који се путем штампаних медија обраћају далеко бројнијој публици. Друго, иако тако експлицитно не каже, ова- 
кав тип текстова повлачи за собом и питање када је пословица типично употребљена. Да ли постоји разлика између типичне пословице у афирмативном облику или директивне пословица. Да ли се ради о типичним, „пословичким“ употребама пословица ако су оне употребљене као наслови (новина, филмова, слика, опера и сл.), као питања у квизовима (када се тражи одговор такмичара о значењу пословица), па и у рекламама? По Чермаку, то се не може сматрати типичном употребом пословица. Заправо, чак и ако пословица уводи неко објашњење ситуације, ако је употребљена као цитат, или даје име неком од секвенци у описивању ситуације, све су то мање типичне употребе пословице. По њему типична употреба пословице је на крају релевантног дела текста, када она означава уопштену ситуацију, апстрахујући оно што је описано као релевантна ситуација у претходном тексту (С̌ermak, 1998, 37-39).

Ова два типа истраживања, путем анкете и путем анализе у корпусу, основа су нашег тарагања за разумевањем савремене употребе пословица. У првом делу савремено, синхронијско познавање пословица испитивали смо путем анкете, док смо у другом делу анализирали појавне облике пословица у корпусу српског језика.

\section{Анкетно истраживање}

Ogбир йословица. У овај део нашег истраживања узели смо укупно 16 пословица за које смо сматрали да су типичне пословице, бицентричне у већини случајева, али у сваком случају сматрали смо да се ниједна од њих не може сврстати у афоризам, цитат, крилатицу, бар не са становишта савременог говорника. Већина има и друга типична обележја пословица: поетску форму (било риму, било неку другу формалну фигуру), значењске фигуре (метафору, хиперболу, контрасте, и сл.), свака може да генерализује низ ситуација, нема потпуно непознатих речи, иако има архаичних ${ }^{1}$. Све доле наведене пословице су изабране из Вукове збирке пословица.

1 Свакако да ту не би долазиле у обзир пословице типа: „Сваки братац себи за ужитак, а Крајини шипак“, коју наводи Марија Клеут, 1999, као застарелу и непознату реалију, насталу поводом историјског догађаја 1751., а забележену у збирци пословица из 1807, Јована Мушкатировића. 
1. Триееж и криееж ярже йо свијейа.

2. Тиха воgа бријеі рони.

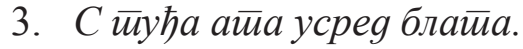

4. Слайка смоква ирреко йлойа.

5. Сјеиила се иреља куђеље уочи неђеље.

6. Све ће бити gо у ћосе браяа.

7. Саg јаја какоћу, а кокоши ћуйе.

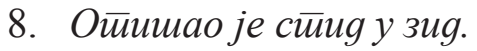

9. Оg немана ииврђеї іраgа нема.

10. Немоїоме йојеgоме, а некћеше све йойише.

11. На соколу је мало меса.

12. На сиройноїа свакоме је лака рука.

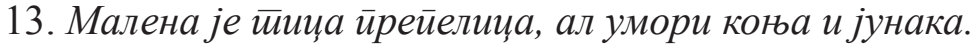

14. Лавица јеgно окойи, али лава.

15. Кућни је йраї највећа йланина.

16. Ко у небо йлује, на образ му йаgа.

Основни циљ овог дела истраживања је био да се обави пробно, пилот истраживање о разумевању значења изрека из Вуковог времена код данашњих одраслих младих говорника српског језика. У анкети је учествовало 100 студената Београдског универзитета (нису студенти филологије) који су претходне школе завршили на језичком подручју штокавског наречја, и то претежно из различитих места у Србији, Црној Гори, Босни и Херцеговини: Бачка Топола, Бања Лука, Београд, Бор, Будва, Чачак, Ћуприја, Горњи Милановац, Гроцка, Хан Пијесак, Ивањица, Јагодина, Кикинда, Косовска Каменица, Косовска Митровица, Котор, Крагујевац, Краљево, Крушевац, Лазаревац, Лебане, Лесковац, Љубовија, Лозница, Мркоњић Град, Ниш, Нови Кнежевац, Нови Пазар, Нови Сад, Панчево, Петровац на Млави, Подгорица, Пожаревац, Пожега, Прокупље, Рашка, Руски Крстур, Шабац, Шипово, Сјеница, Сокобања, Сомбор, Штрпце, Суботица, Трстеник, Ужице, Ваљево, Вараждин, Велика Плана, Велико Градиште, Врање, Врњачка Бања, Вршац, Зајечар, Зрењанин. Овакву регионално разуђену популацију најлакше је пронаћи међу студентима, а генерацијски је оптимално у смислу да су добри представници онога што одражава „савременост“ у језичкој синхронији. Свакако да би за поређење 
било добро имати и више испитаника различитих генерација, поготово што се у литератури сусрећемо са констатацијама да пословице нестају као што нестају друге усмене фолклорне форме (...), те би било интересантно видети да ли се старије генерације разликују од млађих. Но, прикупљање пословица, или њихов одбир није никада могла бити егзактна и до краја исцрпљена процедура - сам Вук Караџић, на крају предговора другог издања из 1849 каже: „Откако се ова књига почела штампати, ја сам до данас наново скупио још неколике стотине новијех пословица [...] зато молим сваког Србина, кад му наиђе на ум каква пословица које у овој књизи нема, да би је записао и са згодном приликом мени послао...“ (стр. LII). Дакле, природа предмета истраживања подразумева још многа даља истраживања, те смо зато ово наше истраживање сматрали почетним истраживањем о синхронијској употреби пословица у нашој средини.

Анкета је рађена 75 минута, и три су захтева била постављена испитаницима:

Да покушају самостално да: а) протумаче значење изреке; б) напишу у којој би се ситуацији могла употребити (кога би или какву појаву могла означавати); и в) ако не разумеју, да напишу шта им је непознато.

Анализа у погледу разумевања значења пословице дала је резултате које можемо представити следећом табелом:

\begin{tabular}{|l|l|l|l|l|l|l|l|l|l|l|l|l|l|l|l|l|}
\hline $\begin{array}{l}\text { Редни број } \\
\text { пословице }\end{array}$ & 1 & 2 & 3 & 4 & 5 & 6 & 7 & 8 & 9 & 10 & 11 & 12 & 13 & 14 & 15 & 16 \\
\hline+ & 6 & 66 & 18 & 23 & 56 & 18 & 22 & 43 & 32 & 26 & 10 & 34 & 51 & 50 & 35 & 14 \\
\hline \pm & 12 & 15 & 18 & 35 & 13 & 18 & 43 & 20 & 24 & 17 & 7 & 22 & 30 & 28 & 33 & 67 \\
\hline- & 82 & 19 & 64 & 42 & 31 & 64 & 35 & 37 & 44 & 57 & 83 & 44 & 18 & 22 & 32 & 19 \\
\hline
\end{tabular}

У случају када је тумачење тачно било дато, нпр. за 2. „Може се употребити за некога ко је миран и ћути, али својом упорношћу долази до циља“" сматрали смо да је тачно протумачио значење и такви одговори су означени као (+). За одговоре који су приближно тачни $( \pm)$ навешемо следећи пример за исту пословицу: „они који су упорни и вредни највише могу постићи“, док смо одговоре без објашњења, или са „Не знам“, „Не разумем“ означили са (-).

Само четири пословице су релативно познате. То су: Tuха воga бријеі рони; Сјейила се ирреља куђеље уочи неђеље; Малена је йица 
ирреиелица, ал умори коња и јунака; Лавица јеgно окойи, али лава. Иако су неке од ових пословица дијалекатски обојене, њихово значење је било прилично лако реконструисати и применити на нове ситуације. За разлику од њих међу најмање познатим, а то су биле 1. Триеж и

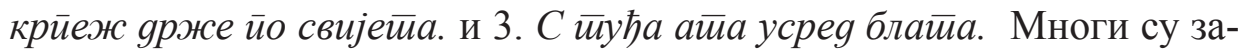

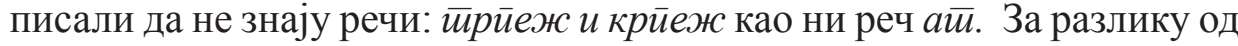
ове две пословице, где има непознатих речи, пословица: На соколу је мало меса., нико није написао да не зна неку реч, што је очекивано, те можемо закључити да се можда симболичка „снага и брзина“ сокола, позната у народном фолклору, понешто изгубила у данашем времену, што је условило неразумевање пословице. Иако можемо да претпоставимо да би се у јаснијем контексту, ови говорници можда боље снашли (рецимо да је „Марко Краљевић скочио на свог ата“, или: „Какав ти је то крпеж на панталонама“) па показали да ипак имају бар пасивно знање ових лексема, у оваквим кратким формама какве су пословице то ипак нису успели. Наравно, било је и оних, мада мањи број, који су написали да не знају речи „преља“, „куђеља“ као термина из данас не много популарних заната, или „ћосе“. Део непознавања, или немогућности тумачења пословица, можемо приписати и неуспешној морфолошкој анализи лексема какве су: какоћу, немоiоme, некћеше, па чак можемо претпоставити да су неки облици $\bar{u}$, немања, случајеви хомографије, те да су пословице биле изговорене, а не у писаној форми можда биле јасније, односно да би испитаници могли закључити шта значе.

Интересантно је како су одговарали на други захтев: у којој би се ситуацији могла употребити пословица. Наиме, већина одговора се

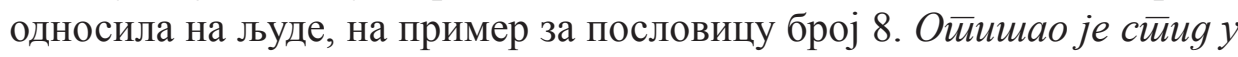
зиg., наводе се следећи одговори: „,за особу без морала и стииgа “, „,Ogноси се на особе које немају йј. не осећају стиия за неке стивари, ситиуације у којима би ирребало gа се сийge“, „За неке безобразне љуgе“. Апстрактнија и уопштенија функција пословице се ређе јавља. На пример за лавица јеgно окойи, али лава, навешћемо следећи пример: „Користии се у сийуацијама каgа неко није учинио нешйо gуіо или че-

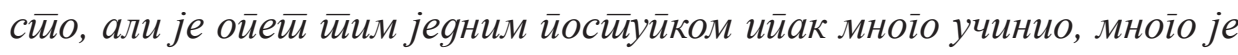
gориичнео нечему“, или за пословицу број 7 (Cag јаја какоћу, а кокоши ћуйе) један одговор је гласио: „Можgа се ова изрека оgноси на ироме- 


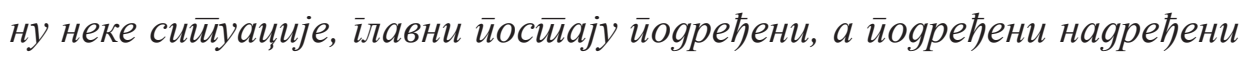
(ілавни)“. А у неким објашњењима ситуација у којим би се могле употребити, има и назнака говорних чинова: „“За особе које кудимо због њиховог лошег понашања““, „када једна особа приговара другој....“, али и свести о некој типичној позицији у тексту: „Након кулминације, када се све открије и ствари изађу на видјело“.

Ова наша пилот анкета показује да и данас постоји делимично разумевање Вукових изрека, као и способност да се одреди њихова могућа употреба. Чињеница је да ниједна од пословица није апсолутно свим испитаницима позната, али се проблеми у разумевању више могу приписати ,унеобичајеној“ творби речи или њиховом облику у неким пословицама, а само у неким случајевима нису препознали архаичне или дијалкетске речи. Само један случај (На соколу...) сугерише измену погледа на „реалију“. У већини случајева, што је за очекивати, познавање пословица је индиковало и логичну претпоставку о ситуацији употребе те пословице. Имплицирана је тиме спорадична употреба, а ако се користе, примењују се на савремене урбане ситуације, тумаче се савременим ситуацијама из личног искуства, и данашњом лексиком: „континуитет“, „посвећеност“, „,валитет“, „квантитет“, само су неке од савремених лексема које се јављају у одговорима испитаника.

Уочене су и регионални модели, рецимо вуковски комуникативни модел. Наши испитаници из Бачке Тополе, Бањалуке, Будве, Хан Пијеска, Ивањице, Кикинде, Косовске Митровице, Котора, Љубовије, Лознице, Мркоњић Града, Новог Пазара, Подгорице, Пожеге, Шипова, Сомбора, Штрпца, Ужица, Зрењанина тумачили су изреке на вуковски начин (породице испитаника из војвођанских градова су колонисти).

\section{Корпусна анализа пословица}

У овом одељку позабавили смо се употребом овог малог скупа пословица са аспекта језичке продукције. Углавном смо се ослањали на 1. корпус писаног језика Математичког факултета Универзитета у Београду, али и на корпусе разговорног и говорног језика прикупљане на Катедри за општу лингвистику Филолошког факултета у Београду који се може поделити на 2. корпус спонтаног разговорног језика и на 
3. говорни политички језик (Емисија Полиграф и снимци Скупштинских говора (дебата). Иако се ови корпуси битно разликују по броју речи (2 милиона МТФ и 120000 речи-токена у говорном корпусу, сматрали смо да почетна анализа употребе пословица на корпусу заслужује проверу на обе врсте материјала.

С обзиром да су изабране пословице у овом истраживању претежно бицентричног типа, претрагу смо вршили по пословици у целини или по кључним речима или комбинацијама речи, на пример:

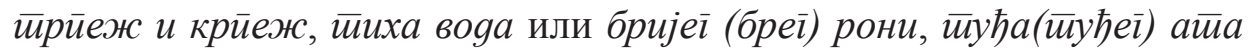

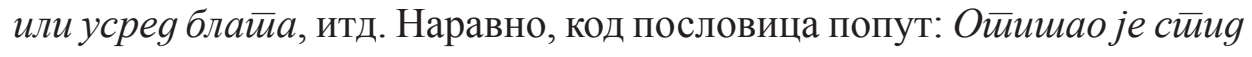
y зиg кључна синтагма је била само cūug y зиg пошто први део пословице не би могао бити никад употребљен као алузија, скраћено позивање на дату пословицу.

Резултати корпусне претраге показали су следеће:

Ниједна од истраживаних пословица се не јавља у корпусима 2. Разговорног језика и 3. Политичком говорном језику. Иако је ограничење то што су релативно мали по броју токена (сваки по око 60000), (а није проверавано да ли су се неке друге пословице, ван нашег одабраног списка можда јавиле), овакав резултат је индикативан, јер може да указује на типове текстова у којима се оне јављају.

У Корпусу српског језика МТФ забележена је употреба само три пословице:

2.Тиха вода бријег рони (9 пута)

4. (Слатка смоква) преко плота?

16. Ко у небо пљује, на образ му пада. (1 пут)

Дакле, упркос обиму овог корпуса, можемо рећи да наше одабране псоловице само ретко се јављају у писаном језику. Чак и ове бројке нису сасвим прецизне. Тако се пословица Tuха воgа бријеї (бреі) рони јавља у свом чистом виду само 9 пута, а овде наводимо два примера:

- Упитан да ли је то већ договорено са СПС , Тадић је одговорио да је рекао довољно и да “"̄uха воgа бреї рони“, због чега око овог питања не би требало правити велику буку, већ сачекати резултат;

- Свестан је наш тенисер ga йиха воgа бреї рони, да Федереров престо мора да поткопава стрпљиво и да му је прва мета Шпанац Надал... 
Неке друге употребе ове пословице показују, можда баш зато што је честа, велику варијабилност:

- као тиха вода ронио његов брег ;

- тиха вода која је почела да рони Федереров трон;

- као тиха вода “рони " и у друге уметничке просторе,

- тиха вода брда ваља;

- Тиха вода асфалт рони (Ово последње је наслов, рецимо, што по Чермаку није права употреба пословице)

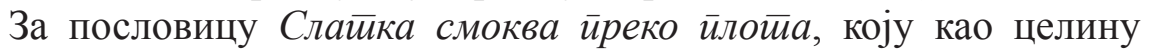
нисмо ниједном нашли, условно смо неке прихватили примере као употребу скраћене верзије пословице:

- Политичар у Србији мора да позелени од муке каgа йойлеga ирреко йлойа,

- са завишћу ћемо гледати ирреко комшијскої йлойа;

- Угледање на одабране у свету, а не на комшију ирреко йлой

- они као добри српски домаћини не гледају йреко йлой $а$, него само у своју авлију

С обзиром на овако мали број појављивања пословица, тестирали смо и Гугл претраживач, односно посматрали смо овај претраживач као корпус, свесни да таква претрага ипак није исто што и претрага језичких копруса (а поготово што је познато да резултат упита „варира у зависности од корисникове историје претходних упита, као и од временског тренутка кад је упит постављен (неке странице на вебу нестају, уместо њих се појављују нове, а временом претраживач мења и оцене релевантности које додељује страницама)" (Утвић, 2013. str. 33-34).

На претраживачу Гуглу, резултати су забележени 15. новембра 2016, а у случају великог броја погодака, прегледано је само првих пет страна. Једном линијом су подвучене пословице које су у нашој анкети објашњене у 50 или више посто случајева. Двоструким линијама подвучене су две пословице које су испитаници најмање разумели.

1. Триееж и крйеж ярже йо свијейа. - 109

2. Тиха воgа бријеі рони. - 11900

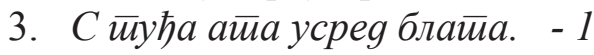

4. Слайка смоква ирреко йлойа. 0

5. Сјейила се иреља куђеље уочи неђеље. - 66

6. Све ће бити ио у ћосе браяа. - 5 
7. Саg јаја какоћу, а кокоши ћуйе.- 0

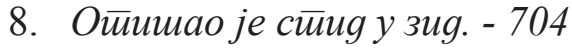

9. Оg немања ииврђеї іраgа нема. 131

10. Немоїоше йојеgоше, а некћеше све йойиме. - 2

11. На соколу је мало меса. - 20

12. На сиройноїа свакоме је лака рука. - 2

13. Малена је тиица иретелища, ал умори коња и јунака. 150

14. Лавица јеgно окойи, али лава. - 344

15. Кућни је йраї највећа йланина. - 660

16. Ко у небо йљује, на образ му йаgа. 878

Иако сматрамо да је ово само иницијални преглед корпуса какав пружа један веб претраживач, ипак су и ове бројке индикативне. Највише помињана и у корпусу писаног српског језика и најпознатија код испитаника је Tuxa воga бреї рони. Остале подвучене пословице које су анкетрирани испитаници релативно добро познавали, јављају су у углавном у збиркама, списковима пословица, изрека, цитата на веб претраживачу (а они су бројни). Неке пословице се, очекивано, употребљавају на блоговима, и то босанским и хрватским (Сјетила се преља куђеље, Трпеж и крпеж). У неким случајевима пословице се јављају често зато што су наслови филмова („Стид у зид“, „Европа преко плота“").

Прокоментарисаћемо и две пословице које су у нашој анкети

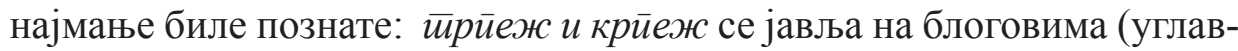
ном хтватским) у којима се коментарише експлицитно или имплицитно финансијска ситуација саговорника и друштва. На пример, израз ириежж и криеж (познат из Андрићеве Госйоцие) јавља се и као цитат на једном блогу: „Ivo Andrić je u priči „Gospođica“ opisao sebičnost, bezosećajnost i pohlepu žene koja je proživela život samotnjački. Moje bake, kao i većina žena na ovim prostorima, predstavljaju suprotnost ovoj gospođici. Sa gospođicom im je zajednička ekonomska politika: „trpež, krреž". Или: "Somboru i Somborcima već decenijama nameću TRPEŽ I KRPEŽ kao način života!“‘(са промоције ЛДП, 2011). Друга, На соколу је мало меса, јавља се као цитат, и то у блоговима "коментарима" за манекенке фирме „Викторија сикрит“, пошто су се чули протести због њихове мршавости: „Znate kako kažu na sokolu malo mesa!““ 


\section{Закључак}

Можемо након овог пилот испитивања, заснованог на избору 16 пословица да се пословице и данас углавном употребљавају и познају, неке мање неке више. Чини се да у случају прављења синхроног пресека савремене употреба треба имати пре свега њихову регионалну варијабилност, затим застарелост неких речи али и необичне творбене формативе које су настале ради „поетизовања“ њихове форме, а које условљавају да их говорници ређе употребљавају или разумеју.

С друге стране, бројност збирки и спискова врло разноликог карактера на веб претраживачу, утицај појединаца, књижевника, новинара, односно медија, и начина на који ти појединци посежу за језгровитим изразима какве су пословице, показује како се пословице ревитализују и изнова постају део ширег језичког знања говорника.

Испитивање синхроне употребе и функције пословица мора бити засновано на више приступа: анкетирањем што ширег броја испитаника из различитих крајева језичког подручја као основним приступом, али га треба допунити и анализом потврђене употребе пословица и функцијама које она имају у ширим контекстима. Упркос све већем дијапазону различитих језичких корпуса, управо се на њиховом примеру може сагледати колико је битно да се у језичким истраживањима бавимо не само књижевним и новинским текстовима, већ и да се шири дијапазон типова и жанрова текстова, а тиме и броја говорника, како би се методолошки употпунило истраживање језика уопште.

\section{Литература}

Čermák, F., (1998). Usage of Proverbs in Today's Czech Language: What the Czech National Corpus Seems to Suggest, in: P. Durčo (ed.), Europhras '97, Bratislava, Akadémia PZ, str. 37-59.

Champion, S. G. (1966). Racial Proverbs. London: Rutledge and Kargan Paul Ltd.

Honeck, R. P. (1982). A developmental study of proverb comprehension. Journal of Psycholinguistic Research, 5 (11), 521-538.

Honeck, R. P. (1997). A proverb in mind: The cognitive science of proverbial wit and wisdom. Mahwah, N.J.: Erlbaum. 
Mieder, W. (1993). Proverbs are Never out of Season: Popular Wisdom in the Modern age. New York: Oxford University Press.

Mieder, W. (2004). Proverbs. A Handbook. London: Green Wood Press-Oxford University.

Savenkova, L., (2008). Elektivnyj kurs "russkie poslovicy i voprosy obŝej paremiologii": soderžanie i metodika prepodavania, Acta Neophilologica 10, 103-111.

Schindler F., (1993). Das Sprichwort im heutigen Tschechischen. Emprirische Untersuchung und semantische Beschreibung. München: O Sagner.

Utvić, M. (2013). Izgradnja referentnog korpusa savremenog srpskog jezika (odbranjena doktorska disertacija), Beograd, Filološki fakultet.

Драгићевић, Р., (2010). Лингвокултуролошка упоредна истраживања

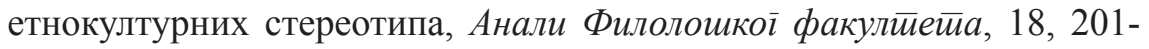
2014.

Иванов, Е.Е., (2007). «Основной паремиологический фонд» русского языка с «паремиологическим минимумом». Доклаgы к XI Межgунароgному коніресс МАПРЯЛ. Могилев, - 27 с.

Иванов, Е.Е. (2009). «Основной паремиологический фонд» русского языка и его соотношение с «паремиологическим минимумом», in: E.E. Иванов, Фразеолоіия іерманских, романских и славянских языков : сборник научных стиайей. - Могилев, МГУ имени А.А. Кулешова, Вып. 1. - С. 137-146.

Јовановић Симић, Ј. (2006). Синйакса и стиилистиика срӣских нароgних йословица, Београд, Филолошки факултет, Научно друштво за неговање и проучавање српског језика.

Караџић, В.С., (1849). Срйске нароgне йословище, Беч: Штампарија Јерменског манастира. 
Vesna Polovina

Zorka Kašić

\section{Summary}

\section{THE SYNCHRONIC VIEW UPON USE AND FUNCTION OF PROVERBS AND SAYINGS}

This paper presents a pilot investigation, based on 16 Serbian proverbs mostly of bicentric type, about their present-day usage and functioning in Serbian. We applied several methodological approaches: thorugh a questionaire given to 100 informants from various regions of Serbian speaking community, giving us basic data about the synchronous status of the proverbs, and then checking the same proverbs in the available corpora of written and spoken language, and also by looking at those proverbs in the Google web as a corpus. While being aware of the advantages and disadvantages of each approach, we were nevertheless been able to conclude that most of these proverbs, taken from a nineteenth century collection by Vuk Karadzic, are still used, or if not, could easily be revived.

We found that most of them can be either used or at least understood, more or less accurately, in their original meaning. How good that knowledge of proverbs is depends on several factors, the most prominent being: the regional variability, the obsolete meaning of a couple of words used in them, some unusual morphological formatives created for "poetic" purpose, and only in case of one word - the loss of the symbolic connotations of the meaning for the contemporary speakers of Serbian. These seem to be the main resaons why some proverbs are less understood.

However, not only the regional variability in their use and function, but also the variability of contexts could be of importance (of text types or genres, the greater number of speakers/writers - as already observed in paremiology) if a more reliable picture of a modern use of proverbs is to be obtained.

Key words: proverbs, corpus, questionnaire, Serbian, present-day usage 